\title{
Chloride binding in concrete: recent investigations and recognised knowledge gaps: RILEM Robert L'Hermite Medal Paper 2021
}

\author{
Klaartje De Weerdt $\mathbb{D}$
}

Received: 21 July 2021 / Accepted: 18 September 2021 / Published online: 11 November 2021

(C) The Author(s) 2021

\begin{abstract}
A theoretical understanding of chloride binding is urgently needed if we are to use the new low- $\mathrm{CO}_{2}$ composite cements in reinforced concrete structures exposed to chloride-loaded environments. The empirical models and "deemed-to-satisfy" rules currently in use will not help in the face of the wide variety of new SCMs now being proposed. Engineers need generic chloride ingress models that can handle the variations in binder chemistry and exposure conditions. This paper reviews a selection of recent investigations by a team of NTNU researchers and international collaborators on various Portland composite cements using a combination of equilibrium chloride-binding experiments and thermodynamic modelling. One of our main findings is that "leaching" simulated by varying the $\mathrm{pH}$ and the calcium concentration has a dominant effect on chloride binding. However, challenges regarding the quantification and characterization of the chloride binding phases have yet to be overcome. To advance in this field we need additional crucial thermodynamic data for chloridebinding hydrates formed by low- $\mathrm{CO}_{2}$ cements containing SCMs, and we need to overcome some experimental challenges. A major break-through would come from understanding the interactions between chlorides and C(-A)-S-H. Part of the answer
\end{abstract}

K. De Weerdt $(\bowtie)$

Department of Structural Engineering, NTNU,

Trondheim, Norway

e-mail: klaartje.d.weerdt@ntnu.no might be found at the atomic level. Finally, mechanistic numerical models are needed to upscale the findings from chloride binding to chloride ingress models. We conclude by showing the significance of such theoretical work on chloride binding for engineers tasked with the construction and maintenance of the reinforced concrete structures that are so vital a part of modern infrastructure.

Keywords Sustainability - Marine environment . Thermogravimetric analysis · SEM-EDS · C-S-H

\section{Introduction}

Chloride-induced corrosion of steel reinforcement is one of the main degradation mechanisms for reinforced concrete structures worldwide and is therefore a major threat to our global infrastructure [1]. Typical sources of chlorides are de-icing salts and sea water. Chlorides penetrate the concrete cover protecting the reinforcement steel and will cause corrosion when they reach a critical level at the depth of the steel reinforcement, as illustrated in Fig. 1. It is this corrosion of the reinforcement which generally causes the end of the service life of a reinforced concrete structure.

A chloride profile gives the total chloride content in $\%$ by wt. of concrete as a function of depth from the 
Fig. 1 Sketch illustrating chloride ingress in the concrete cover

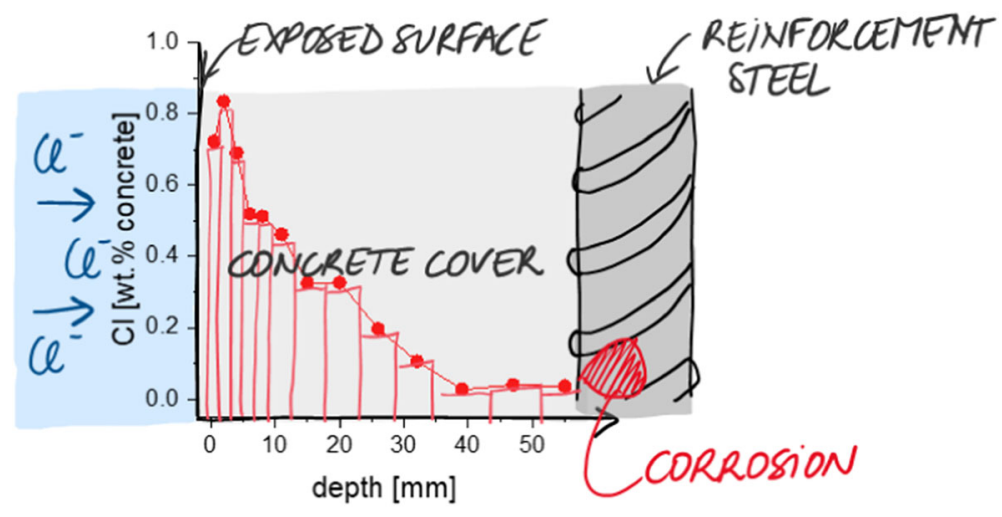

exposed surface (see Fig. 1). During the design stage of a structure, chloride profiles help engineers select a concrete composition with sufficient resistance to chloride ingress to ensure the required design service life. Chloride profiles are also used to assess the condition of existing structures with regard to chloride-induced reinforcement corrosion and to predict their remaining service life. However, the mechanisms of chloride ingress in concrete are still not fully understood. This means that the design and maintenance of many reinforced concrete structures still rely largely on experience-based, "deemed-to-satisfy" rules. Commonly used engineering models for service life prediction, such as the fib model code [2] and ISO 16204 [3], are empirical models relying on curvefitting of chloride profiles from laboratory and longterm field-exposed concrete.

The problem with the current models is that there is now tremendous pressure to develop new low- $\mathrm{CO}_{2}$ composite cements, because the cement industry alone currently produces about $7 \%$ of all global $\mathrm{CO}_{2}$ emissions [4, 5]. The supplementary cementitious materials (SCMs) most commonly used in composite cements are becoming scarcer, so we need new SCMs not covered by the current models. Moreover, we are designing structures for much longer service lives and want to extend those of existing structures. All these sustainability factors combine to make it urgent to develop generic mechanistic models for the accurate prediction of the durability of the concrete we make.

This paper focuses on one crucial piece of the puzzle, chloride binding, which reflects the ability of hydrated cement paste to accumulate chlorides in the hydrates formed. It should be noted that generic mechanistic chloride ingress models should also account for the impact of new sustainable binders on the porosity and moisture state of the concrete. This very challenging work is at least as important as chloride binding when it comes to understanding chloride ingress in concrete [6,7], but lies beyond the scope of this paper.

The next section reviews some recent work of my team of researchers in Norway and international collaborators. For a broader state-of-the-art review, I refer to the comprehensive books written by Shi et al. [8], Tang et al. [9], and Bertolini et al. [10], and articles by Justnes [11], Yuan et al. [12], and Zibara [13].

The third section indicates the main knowledge gaps in this field with a view to focusing the efforts of the research community and encouraging support from funding institutions and industry, and the conclusion summarizes why such research is so important for the engineers responsible for the construction and maintenance of reinforced concrete structures exposed to chlorides.

\section{Chloride binding}

Our investigations combined equilibrium chloride binding experiments with thermodynamic modelling. In the former, the crushed hydrated cement paste is left to equilibrate in the chloride-containing solution, and the chloride-binding capacity is revealed by the reduction in chloride concentration in the exposure solution. For the thermodynamic modelling, we used Gibbs free energy minimization software (GEMS) [14], combined with general databases and the cement-specific Cemdata18 database [15]. This 


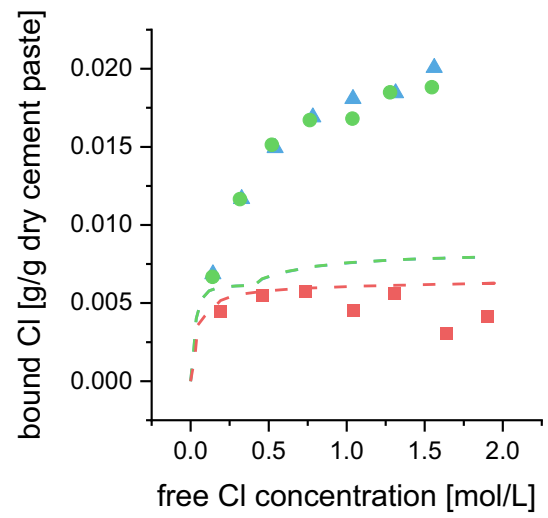

Fig. 2 The amount of bound chloride (left) and $\mathrm{pH}$ (right) of the exposure solution as a function of free chloride concentration for hydrated PC paste in equilibrium with $\mathrm{MgCl}_{2}, \mathrm{CaCl}_{2}$ or $\mathrm{NaCl}$ solutions. The experimental results are shown with symbols;

includes Balonis et al.'s thermodynamic dataset [16] for Kuzel's salt and Friedel's salt as pure phases, and also accounts for the solid solutions between Friedel's salt and carbonate AFm, and Friedel's salt and hydroxy-AFm. The advantage of equilibrium chloride binding methods is that there is sufficient homogenous cement paste to characterize the changes in the solids and in the pore solution. This closed system equilibrium set-up also allows us to combine the experimental results with thermodynamic modelling (another closed system), which empowers us to investigate the fundamental mechanisms of chloride binding. We should note that the chloride binding predicted by the thermodynamic model does not include adsorption of ions onto the $\mathrm{C}(-\mathrm{A})-\mathrm{S}-\mathrm{H}$.

The following sub-sections discuss three of the major factors affecting chloride binding in any composite cement: (i) pore solution composition, where the cations are of particular importance, (ii) the impact of leaching, which changes the composition of the hydrates, and (iii) the impact of SCMs.

\subsection{The effect of cations}

We investigated the cation effect of chloride salts by comparing binding in Portland cement (PC) paste for $\mathrm{NaCl}, \mathrm{CaCl}_{2}$ and $\mathrm{MgCl}_{2}$ exposures in the range of 0.2 to $2 \mathrm{~mol} / \mathrm{L}$ free chloride concentrations [17]. For comparison, sea water has a chloride concentration of approx. $0.5 \mathrm{~mol} / \mathrm{L}$, while the higher concentrations are more relevant for exposure to de-icing salts. $\mathrm{NaCl}$, $\mathrm{CaCl}_{2}$ and $\mathrm{MgCl}_{2}$ are all used as de-icing salts, and

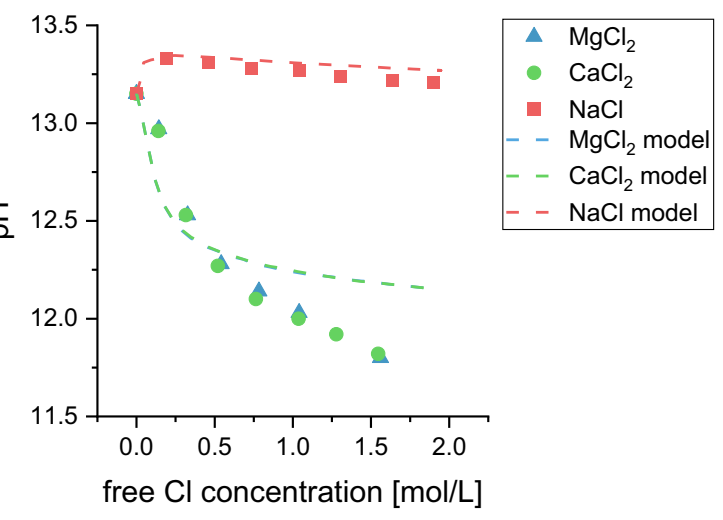

dotted lines show the thermodynamic model results. Note that the modelled results for $\mathrm{MgCl}_{2}$ and $\mathrm{CaCl}_{2}$ overlap. The solution/solid ratio is approx. 2:1 [17].

$\mathrm{MgCl}_{2}$ is also used as dust control agent on roads and in tunnels. Sea water contains mainly $\mathrm{NaCl}$ and a range of other salts including some $\mathrm{MgCl}_{2}$.

Figure 2 shows the binding isotherms and corresponding $\mathrm{pH}$ of the exposure solutions. We observed more chloride binding for the bivalent cations, calcium and magnesium, than for the monovalent sodium, confirming other results [18-22]. Moreover, the $\mathrm{pH}$ of the exposure solution decreased with $\mathrm{CaCl}_{2}$ and $\mathrm{MgCl}_{2}$ addition, again confirming other results $[18,20]$, while a slight initial increase in $\mathrm{pH}$ was observed with $\mathrm{NaCl}$ addition.

Combining equilibrium binding experiments with thermodynamic modelling, enabled us to investigate the mechanisms behind this cation effect. According to the thermodynamic model, the initial slight increase in $\mathrm{pH}$ with $\mathrm{NaCl}$ addition could be attributed to changes in the AFm and AFt, e.g., the transformation of hemicarbonate to Friedel's salt leads to the release of hydroxyl ions [17]. Addition of $\mathrm{CaCl}_{2}$ or $\mathrm{MgCl}_{2}$ to the system leads to the precipitation of $\mathrm{Ca}(\mathrm{OH})_{2}$ or $\mathrm{Mg}(\mathrm{OH})_{2}$ causing a reduction in $\mathrm{pH}$, as also indicated by Tritthart [18]. Addition of $\mathrm{CaCl}_{2}$ or $\mathrm{MgCl}_{2}$ also causes an increase in the calcium concentration in the solution, as shown in Fig. 3. The increase in calcium in the pore solution is the same for $\mathrm{MgCl}_{2}$ exposure as for $\mathrm{CaCl}_{2}$ exposure because the magnesium added in solution is replaced by calcium from the dissolution of $\mathrm{Ca}(\mathrm{OH})_{2}$, which is compensated by an equimolar precipitation of $\mathrm{Mg}(\mathrm{OH})_{2}$ (see Fig. 4). Within the investigated range, the only difference is the gradual replacement of $\mathrm{Ca}(\mathrm{OH})_{2}$ by $\mathrm{Mg}(\mathrm{OH})_{2}$ in the solids 
Fig. 3 The modelled elemental concentration of $\mathrm{Ca}$ in the exposure solution as a function of free chloride concentration for hydrated $\mathrm{PC}$ paste in equilibrium with $\mathrm{MgCl}_{2}, \mathrm{CaCl}_{2}$ and $\mathrm{NaCl}$ solutions. Results for the $\mathrm{MgCl}_{2}$ solution are not visible because they overlap with the $\mathrm{CaCl}_{2}$ results [17]
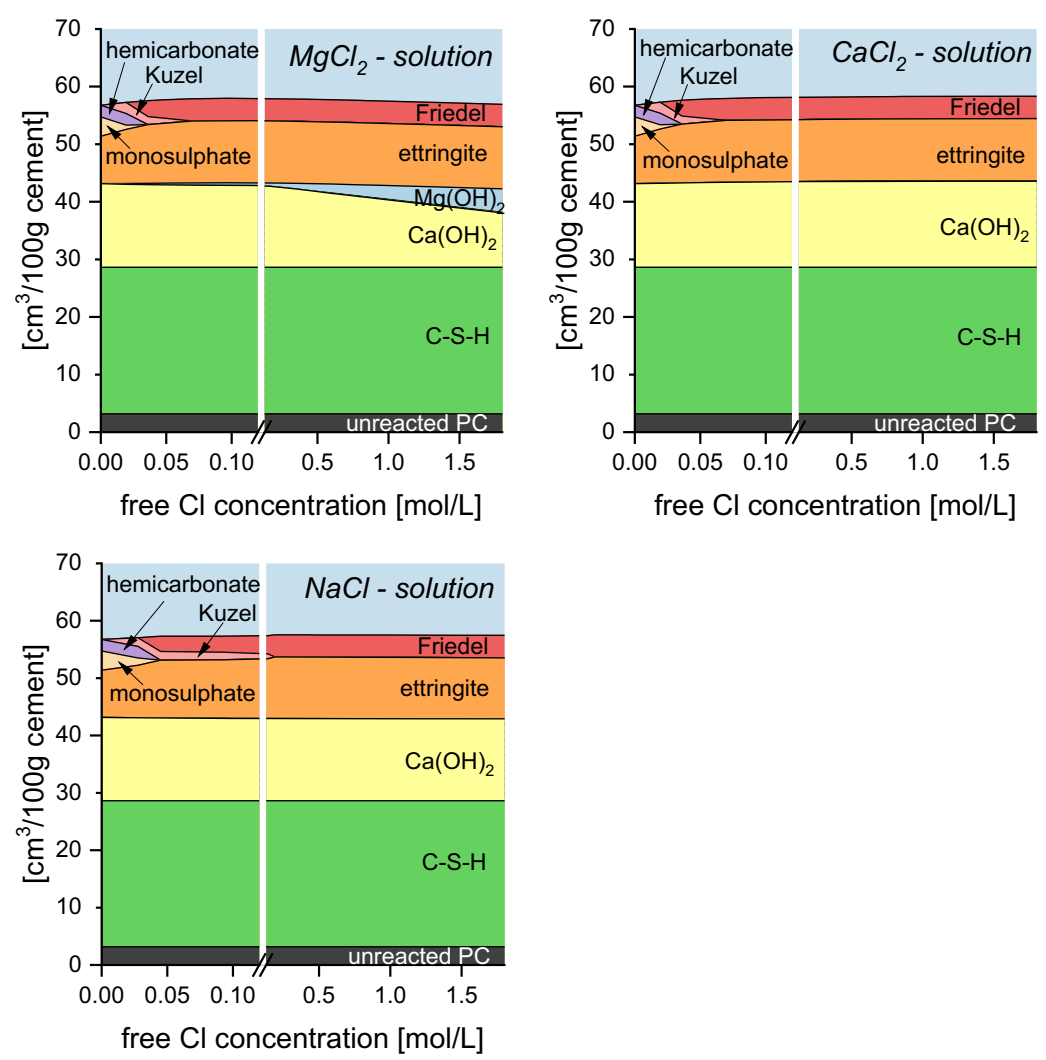

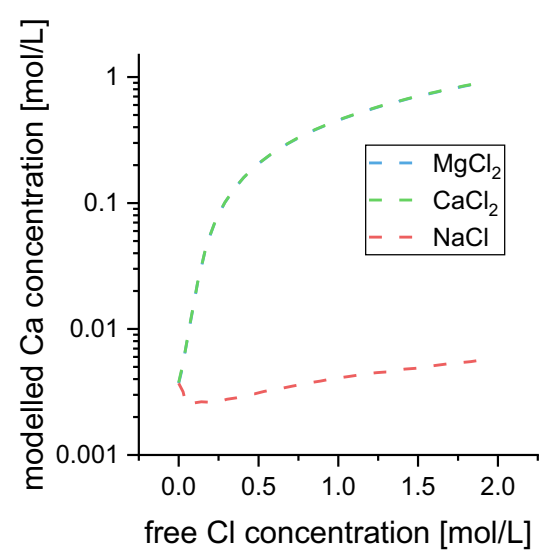

Fig. 4 The modelled volume of hydration phases for hydrated $\mathrm{PC}$ paste in equilibrium with $\mathrm{MgCl}_{2}$ (left), $\mathrm{CaCl}_{2}$ (middle), and $\mathrm{NaCl}$ (right) exposure solutions as a function of free chloride concentration [17]

(see Fig. 4). Upon further addition of $\mathrm{CaCl}_{2}$ or $\mathrm{MgCl}_{2}$, the calcium concentration of the system continues to increase up to the equilibrium concentration for saturated $\mathrm{Ca}(\mathrm{OH})_{2}$, i.e., $0.02 \mathrm{~mol} / \mathrm{L}$ at $\mathrm{pH} 12.5$ at $25{ }^{\circ} \mathrm{C}$ (see Fig. 3), which suppresses the dissolution of
$\mathrm{Ca}(\mathrm{OH})_{2}$ and instead causes further $\mathrm{Ca}(\mathrm{OH})_{2}$ precipitation, resulting in a continued gradual decrease of the $\mathrm{pH}$, as shown in Fig. 2.

Although the thermodynamic model is able to predict the decrease in the $\mathrm{pH}$ after $\mathrm{CaCl}_{2}$ or $\mathrm{MgCl}_{2}$ addition, it still underestimates the decrease considerably (see Fig. 2). This means there is another mechanism decreasing the $\mathrm{pH}$. This could be the increased adsorption of calcium onto the $\mathrm{C}(-\mathrm{A})-\mathrm{S}-\mathrm{H}$ surface at higher calcium concentrations, leading to the release of charge-balancing hydron $(\mathrm{H}+)$ ions from the silanol groups [23-25]. A similar mechanism for the decrease in $\mathrm{pH}$ has been suggested by Tritthart [18] and Wowra and Setzer [20], though the actual calcium sorption was first demonstrated by Shi et al. [26]. According to Labbez et al. [23] and Plusquellec and Nonat [25], this mechanism also explains the considerably higher chloride binding for $\mathrm{CaCl}_{2}$ and $\mathrm{MgCl}_{2}$ exposures than for $\mathrm{NaCl}$ exposure. This is because the calcium sorption renders the $\mathrm{C}(-\mathrm{A})-\mathrm{S}-\mathrm{H}$ surface more positively charged, enabling the adsorption of chloride ions in the diffuse layer. This also explains why we 
found that about twice as much (monovalent) chloride is adsorbed as (bivalent) calcium [26].

An alternative explanation for the differences between the measured and the modelled $\mathrm{pH}$ and chloride binding for higher chloride concentrations could be the formation of some other phase which takes up chloride, hydroxyl and calcium ions and which is not included in the thermodynamic model, e.g., a calcium hydroxychloride compound. However, no such compound was observed in our cation study [17].

\subsection{The impact of leaching on chloride binding}

In concretes exposed to sea water or a $\mathrm{NaCl}$ solution, a lower $\mathrm{pH}$ is imposed at the surface of the concrete leading to significant leaching and lowering of the $\mathrm{pH}$ of the pore solution, which affects chloride binding. So, we developed an experimental set-up to further investigate the impact of $\mathrm{pH}$ on chloride binding [27, 28]. Figure 5 (left) shows chloride binding isotherms for PC paste exposed to $\mathrm{NaCl}$ and $\mathrm{CaCl}_{2}$ solutions. To investigate the $\mathrm{pH}$ effect, we started with a PC paste sample in equilibrium with an $\mathrm{NaCl}$ exposure solution of $1.1 \mathrm{~mol} / \mathrm{L}$. This is a chloride concentration corresponding to the plateau of the $\mathrm{NaCl}$ chloride binding isotherm, at which additional chloride should not lead to a significant increase in chloride binding. To increase the chloride concentration and lower the $\mathrm{pH}$ at the same time, we added $\mathrm{HCl}$ (see Fig. 5 left).

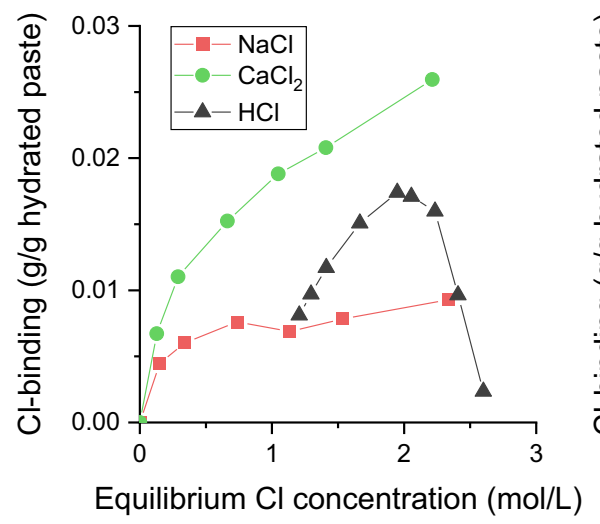

Fig. 5 Left: Chloride binding isotherms for hydrated PC paste exposed to $\mathrm{NaCl}$ and $\mathrm{CaCl}_{2}$ solutions. The datapoints labelled $\mathrm{HCl}$ were obtained by gradually adding $4 \mathrm{~mol} / \mathrm{L} \mathrm{HCl}$ to a $1.1 \mathrm{~mol} / \mathrm{L} \mathrm{NaCl}$-exposed sample. The $\mathrm{HCl}$ data has been corrected for the dissolution of hydrated cement paste, assuming
The problem with this acidification is the gradual dissolution of the hydrated cement paste (see Fig. 6) and the consequent increase in the volume of the exposure solution, as well as an increase in calcium concentration. We corrected for the dissolution due to the addition of $\mathrm{HCl}$ by using the iron in the solids as an "internal standard" to quantify the original amount of hydrated cement paste, as described by Hemstad et al. [28]. A similar approach was first used to determine the mass loss from leaching by Machner et al. [29].

Figure 5 (left) shows how the addition of $\mathrm{HCl}$ to the $1.1 \mathrm{~mol} / \mathrm{L} \mathrm{NaCl}$-exposed sample leads to an increase in the amount of bound chloride to a maximum at about $2 \mathrm{~mol} / \mathrm{L}$, which then decreases with further additions of $\mathrm{HCl}$. Figures 5 (right) shows the data as a function of the $\mathrm{pH}$ of the exposure solution. Here the bound chloride increases from 0.007 to about $0.0175 \mathrm{~g}$ chloride/g paste as the $\mathrm{pH}$ decreases from about 13 to 12. When the $\mathrm{pH}$ drops below 12 , the chloride binding decreases. For exposure to $\mathrm{CaCl}_{2}$, chloride binding increases as high as $0.025 \mathrm{~g}$ chloride/g paste for a $\mathrm{pH}$ just below 12. The difference in chloride binding between $\mathrm{HCl}$ and $\mathrm{CaCl}_{2}$-exposure is due to the difference in available calcium, as demonstrated with modelled data in Fig. 7. At $\mathrm{pH}=12$, all portlandite is dissolved in the $\mathrm{HCl}$ system, so the system becomes calcium-deficient, while the $\mathrm{CaCl}_{2}$ system still has a portlandite buffer.

We quantified the amount of chloride-containing AFm using thermogravimetric analysis (TGA) and the $\mathrm{Cl} / \mathrm{Al}$ molar ratio of the AFm using scanning electron

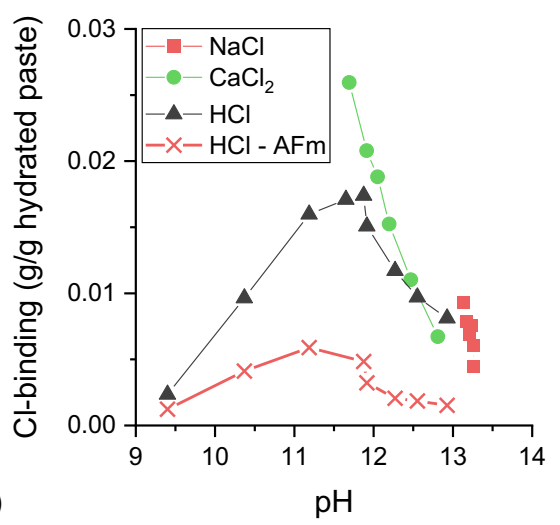

a density of $2 \mathrm{~g} / \mathrm{ml}$ for the dissolved material. Right: The same chloride binding data, but expressed as a function of the $\mathrm{pH}$ at equilibrium. The estimated chloride binding in the AFm is also indicated [28] 


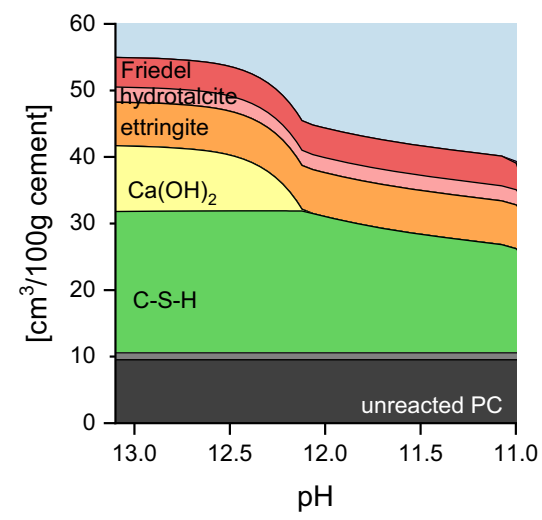

Fig. 6 The modelled volume of hydration phases for hydrated $\mathrm{PC}$ paste as a function of the $\mathrm{pH}$ of the exposure solution. The $\mathrm{pH}$ is gradually lowered by adding $4 \mathrm{~mol} / \mathrm{L} \mathrm{HCl}$ to a $1.1 \mathrm{~mol} / \mathrm{L}$ $\mathrm{NaCl}$-exposed PC paste sample [28]

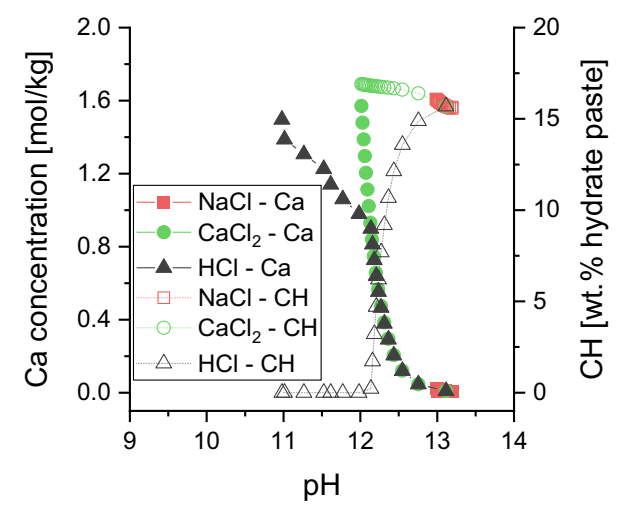

Fig. 7 The calcium concentration and portlandite content $(\mathrm{CH})$ for hydrated $\mathrm{PC}$ paste exposed to $\mathrm{NaCl}, \mathrm{CaCl}_{2}$ and $\mathrm{HCl}$ solutions, as determined by thermodynamic modelling

microscopy with energy-dispersive spectroscopy (SEM-EDS). They are shown as a function of $\mathrm{pH}$ in Fig. 8. The amount of AFm increases when the $\mathrm{pH}$ decreases from 13 to 11 , but decreases as the $\mathrm{pH}$ decreases further. In contrast, the total amount of bound chloride already starts to decrease when the $\mathrm{pH}$ reaches 12 . This might indicate that the physical binding of chlorides in the $\mathrm{C}(-\mathrm{A})-\mathrm{S}-\mathrm{H}$ has already started to decrease in this $\mathrm{pH}$ range, whereas the binding in AFm is still increasing.

Also very interesting is the increase in the $\mathrm{Cl} / \mathrm{Al}$ molar ratio of the AFm from about 0.5 at $\mathrm{pH}=13$, to almost 1 at $\mathrm{pH}=12$ and below. In previous studies, we calculated the amount of bound chloride in AFm assuming the stoichiometry of Friedel's salt, but this gives a result lower than expected for $\mathrm{pH}$ above 12 , possibly indicating the presence of $\mathrm{OH}^{-}$in the interlayer of Friedel's salt. We conclude that one should always verify the $\mathrm{Cl} / \mathrm{Al}$ ratio of the AFm! This can be done by SEM-EDS [28, 30]. Alternatively, one could use the promising approach described in Maraghechi et al. [7], Sui et al. [31], and Avet et al. [32], where they use Rietveld refinement X-ray diffraction (XRD-Rietveld) to both quantify the Friedel's salt and determine its $\mathrm{Cl} / \mathrm{Al}$ ratio.

In Hemstad et al. [28], we did not investigate the evolution of the chloride uptake by C(-A)-S-H as a function of $\mathrm{pH}$ directly, but indirectly one can get an idea of the potential contribution of C(-A)-S-H to the chloride uptake by subtracting the chloride bound in AFm from the total amount of bound chloride, as shown in Fig. 5 (right). We should note that the potential chloride bound in AFm was estimated based on the mass loss measured by TGA, cf. Figure 8 (left), and the chloride content, cf. Figure 8 (right). The contribution of $\mathrm{C}(-\mathrm{A})-\mathrm{S}-\mathrm{H}$ seems to be considerable and to depend strongly on the $\mathrm{pH}$. This needs to be verified experimentally.
Fig. 8 Left: Mass loss from AFm determined by TGA in the $250-400{ }^{\circ} \mathrm{C}$ range expressed as \% by wt. of hydrated paste. Right: $\mathrm{Cl} / \mathrm{Al}$ molar ratio of the AFm determined by SEM-EDS. Both in function of the $\mathrm{pH}$ of the exposure solution at equilibrium [28]
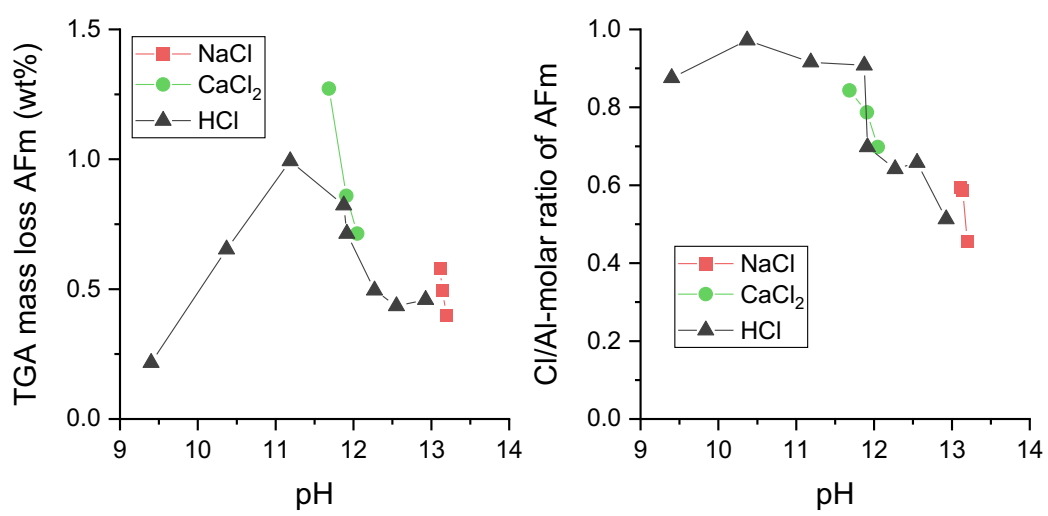
2.3 The impact of SCMs on chloride binding in Portland composite cements

The use of SCMs in Portland composite cements can change the phase assemblage of the hydrated cement paste and thereby its chloride binding properties $[13,19,33]$. Silica fume is often used as a model SCM for studying the impact of silicate-rich SCMs, because it consists mainly of highly reactive amorphous silicate. The addition of silica fume reduces chloride binding compared to plain PC $[13,19,33,34]$. This has been attributed to the dilution of the aluminate phases and the changes silica fume introduces to the C(-A)-S-H composition, e.g., a decrease in $\mathrm{Ca} / \mathrm{Si}$ ratio $[13,19,33,34]$. SCMs which contribute with reactive aluminates, such as metakaolin, fly ash or slag, can lead to an increase in the amount of AFm and thereby more chloride binding. Very few studies have investigated the changes in the contribution of physical binding in $\mathrm{C}(-\mathrm{A})-\mathrm{S}-\mathrm{H}$ and chemical binding in AFm when SCMs are added $[7,26,32,35]$.

We used metakaolin as the model material for investigating the impact of an SCM which brings both aluminates and silicates to the system on chloride binding. In one study [26], we replaced white PC with metakaolin (32\% by wt.) or with a combination of metakaolin ( $26 \%$ by wt.) and limestone ( $6 \%$ by wt). In another study [36], we replaced grey Portland cement (PC) with metakaolin (15\% by wt.). In both studies, we used a similar set-up as before [17, 26, 35] to investigate chloride binding both for $\mathrm{NaCl}$ and $\mathrm{CaCl}_{2}$ exposures (see Fig. 9). The two set-ups differed slightly in the mass ratio of hydrated paste to exposure solution: 2:1 [26] and 1:1 [36].

TGA confirmed that the addition of metakaolin increases the amount of chloride-containing AFm in the system. Moreover, the chloride uptake upon exposure to $\mathrm{CaCl}_{2}$ is higher than with exposure to $\mathrm{NaCl}$ (Fig. 9). In other studies, we attributed this difference mainly to changes in the chloride uptake in the C(-A)-S-H [17, 26, 35], while here we attributed it mainly to the formation of additional chloride-containing AFm enabled by the exposure to $\mathrm{CaCl}_{2}$ in the otherwise calcium-deficient system, and the contribution of chloride adsorption in the C(-A)-S-H was thought to be limited [26]. However, we did not confirm the chloride content in the AFm, so it might be that the contribution of the AFm to the chloride binding was overestimated, and the chloride adsorbed by $\mathrm{C}(-\mathrm{A})-\mathrm{S}-\mathrm{H}$ might have been underestimated since it was determined by subtracting the chemical binding in the AFm from the total chloride binding.

We also investigated the changes in chloride binding when plain PC is replaced with silica fume ( $15 \%$ by wt) or with a combination of metakaolin and silica fume (each $15 \%$ by wt) [36]. As before, we used TGA for the quantification of the chloride binding AFm and portlandite, but since we did not quantify the chloride content of the AFm, we were not able to quantitatively distinguish the contribution of the AFm and $\mathrm{C}(-\mathrm{A})-\mathrm{S}-\mathrm{H}$ to the total chloride uptake. In this case, however, we used ${ }^{27} \mathrm{Al} \mathrm{NMR}$ and ${ }^{29} \mathrm{Si}$ NMR spectroscopy for the characterization of the C(-A)-S-H. Figure 9 shows that replacing part of the $\mathrm{PC}$ with silica fume led to a similar or slightly lower amount of bound chloride compared to the PC reference, which confirms other studies [13, 19, 33, 34].

The silica fume replacement resulted in a decrease in the amount of chloride-containing AFm and an increase in the amount of $\mathrm{C}(-\mathrm{A})-\mathrm{S}-\mathrm{H}$, which seemed to cancel each other out when it comes to chloride binding. Interestingly, the combination of silica fume and metakaolin as replacement did not increase the amount of bound chloride either, even though the replacement of PC with metakaolin on its own did. It seems that the combination of silica fume and metakaolin makes the system portlandite-deficient, which increases the aluminate content of the $\mathrm{C}(-\mathrm{A})-\mathrm{S}-\mathrm{H}$ resulting in a decrease in the amount of chloride-containing AFm. Moreover, the calcium content probably decreases, resulting in a potentially lower uptake of chlorides by the C(-A)-S-H. For more information, see Baba Ahmadi et al. [36].

We made a very interesting observation when using ${ }^{27} \mathrm{Al} \mathrm{NMR}$ and ${ }^{29} \mathrm{Si}$ NMR [36]: chloride exposure seems to reduce the aluminium uptake of the $\mathrm{C}(-\mathrm{A})-\mathrm{S}-\mathrm{H}$. This would make more aluminium available to form chloride-containing AFm. This merits further investigation because it would mean that we might not be able to use the phase composition of an unexposed sample to directly predict the chloride uptake.

We also investigated the chloride-binding capacity of composite cements containing dolomite ( $40 \%$ by wt) and a combination of dolomite ( $35 \%$ by wt.) and metakaolin ( $5 \%$ by wt) [35]. The dolomite gave rise to hydrotalcite formation, which is a rather slow reaction, so we accelerated it by curing the cement pastes at $60{ }^{\circ} \mathrm{C}$. We showed that hydrotalcite can contribute to 


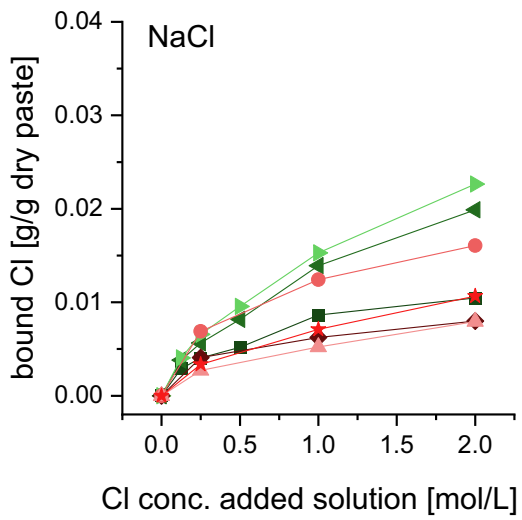

Fig. 9 The amount of bound chloride per gram of dry cement paste as a function of the chloride concentration of the added $\mathrm{NaCl}$ or $\mathrm{CaCl}_{2}$ solution. The legend shows the composition of the cements (in \% by wt.): wPC = white Portland cement, $\mathrm{M}=$ metakaolin, $\mathrm{L}=$ limestone, $\mathrm{PC}=$ grey Portland cement,

chloride binding in the cement paste (1-1.8 mol chlorine per mol hydrotalcite) to the same extent as Friedel's salt ( 2 mol chlorine per mol Friedel's salt). The binding capacity of the hydrotalcite was found to depend on its exact composition as well as the activity of ions, such as carbonates in the exposure solution, which compete with the chloride to be taken up by hydrotalcite. Our findings agree well with Ke et al. [37], who investigated chloride uptake in pure hydrotalcite. Taking into account the binding capacity of hydrotalcite can be very important for cements with magnesium-rich SCMs, such as slags, because they may contain considerable amounts of reactive magnesium [38].

\section{Knowledge gaps}

Our overall aim should be to develop generic models that can predict chloride profiles in concrete for the whole range of binder compositions and exposure conditions. This section focuses on research opportunities with large potential related to chloride binding in layered double hydroxides (LDHs), calcium hydroxychlorides (CAOXY), and $\mathrm{C}(-\mathrm{A})-\mathrm{S}-\mathrm{H}$ in terms of both experiments and modelling. We discuss some experimental pitfalls when investigating chloride binding, and why we need multi-ionic numerical models to understand its role in chloride ingress. and SF = silica fume. The results from [26] are shown in shades of green and the results from [36] are shown in red. It should be noted that the mass ratio of hydrated paste to exposure solution was 2:1 for [26] and 1:1 for [36]

\subsection{Chloride binding in LDHs}

LDH phases, such as hydrotalcite and AFm (including strätlingite), all have a very similar structure, which explains why they take up chloride in comparable ways.

Their general formula is $\left[M_{1-x}^{I I} M_{x}^{I I I}(\mathrm{OH})_{2}\right]^{x+}\left[A^{m-}\right]_{x / m} \cdot n H_{2} O$. Their main layer structure is similar to the portlandite $\left(\mathrm{Ca}(\mathrm{OH})_{2}\right)$ or brucite $\left(\mathrm{Mg}(\mathrm{OH})_{2}\right)$ lattice structure.

\subsubsection{AFm}

In the case of AFm, one third of the divalent cations $\mathrm{Ca}^{2+}\left(M_{1-x}^{I I}\right.$ in the general formula) in the portlandite $\left(\mathrm{Ca}(\mathrm{OH})_{2}\right)$ lattice structure are replaced by trivalent $\mathrm{Al}^{3+}$ or $\mathrm{Fe}^{3+}$ cations ( $M_{x}^{I I I}$ in the formula), resulting in a positively charged layered structure. The positive charge of the layers is compensated by intercalated anions $\left(\left[A^{m-}\right]_{x / m}\right)$, such as $\mathrm{SO}_{4}{ }^{2-}, \mathrm{CO}_{3}{ }^{2-}, \mathrm{OH}^{-}$, or $\mathrm{Cl}^{-}$, in the interlayer space. AFm efficiently binds chloride, and chloride-containing AFm phases are included in thermodynamic models using the thermodynamic data collected by Balonis et al. [16]. They studied pure AFm systems at a $\mathrm{pH}$ of about 12 and determined the thermodynamic data for Friedel's salt and Kuzel's salt included in the Cemdata18 thermodynamic database [15]. They observed solid solution between hydroxy AFm and Friedel's salt (for $\mathrm{Cl}^{-}$/ $\left.\left(\mathrm{Cl}^{-}+\mathrm{OH}^{-}\right) \geq 0.2\right), \quad$ and between 
monocarboaluminate and Friedel's salt (for $\mathrm{Cl}^{-} /$ $\left.\left(\mathrm{Cl}^{-}+0.5 \mathrm{CO}_{3}{ }^{2-}\right) \geq 0.1\right)$. There is no solid solution between Friedel's salt and monosulphate, but instead Kuzel's salt is formed. However, the current thermodynamic data has been obtained for a $\mathrm{pH}$ of about 12 and a carbonate-saturated system. There is a need to extend the AFm thermodynamic data for varying $\mathrm{pH}$ and, for instance, for carbonate-deficient systems that form hemicarboaluminates.

Since chloride-containing AFm (Cl-AFm) is crystalline, there are two main experimental techniques which have been applied for its quantification in hydrated cement paste or mortar, namely TGA (due to its distinct mass loss steps caused by the loss of crystalline water) and XRD-Rietveld (due to its distinct diffraction patterns).

With TGA, the amount of chloride-containing AFm is determined based on the distinct mass loss between approx. 200 and $400{ }^{\circ} \mathrm{C}$, which has been associated with the release of the water in the main layer of Friedel's salt [6]. However, this mass loss can be associated with either pure Friedel's salt, Friedel's salt containing other anions, or with hydrotalcite. This means that TGA quantification should be combined with EDS analysis to determine the amount of chloride bound in the AFm [28, 32]. The great advantage of using TGA to quantify $\mathrm{Cl}$-AFm is that it can be applied on paste samples [28] as well as profile-ground mortar or concrete samples [6,39].

XRD-Rietveld has been used by Sui et al. [31] to quantify the amount of chloride-containing AFm and determine its composition as a solid solution of hemicarbonate and Friedel's salt. However, XRDRietveld analysis of AFm phases is very challenging because they are unstable during measurement, which leads to evaporation and/or carbonation. Balonis et al. [16] specify that such measurements should be done on wet samples, e.g., covered by foil.

\subsubsection{Strätlingite and hydrotalcite}

Strätlingite has the same main layer structure as other AFm phases, but contains aluminosilicate anions in the interlayer. In hydrotalcite, the main layer structure is derived from brucite $\left(\mathrm{Mg}(\mathrm{OH})_{2}\right)$ instead of portlandite, and a variable fraction of the divalent $\mathrm{Mg}^{2+}$ cations in the brucite structure are replaced by trivalent $\mathrm{Al}^{3+}$ cations.
We need to determine thermodynamic data on the chloride uptake in hydrotalcite and strätlingite. The importance of the potential contribution of these phases to chloride binding has been shown by Ke et al., who report a chloride-binding capacity for synthesized hydrotalcite and strätlingite of respectively $25 \%$ and $20 \%$ by wt., compared to $13 \%$ for Friedel's salt [37]. Moreover, Machner et al. have demonstrated that hydrotalcite can contribute as much to chloride binding in composite cements as Friedel's salt [35]. It should be noted that these systems are more complex than that of AFm, due for instance to the possible variations in the $\mathrm{Mg} / \mathrm{Al}$ ratio for hydrotalcite and the semi-crystallinity of strätlingite.

Research on this topic is extremely important because hydrotalcite and strätlingite are commonly encountered in low- $\mathrm{CO}_{2}$ binders, such as Portland composite cements with magnesium-rich SCMs $[35,40]$ or with high SCM replacement levels, and in alkali-activated systems [37].

\subsection{Chloride binding by calcium} hydroxychlorides

Calcium hydroxychlorides (CAOXY) form primarily through the reaction of portlandite $\left(\mathrm{Ca}(\mathrm{OH})_{2}\right)$ with calcium chloride $\left(\mathrm{CaCl}_{2}\right)$ or magnesium chloride $\left(\mathrm{MgCl}_{2}\right)$ and water. Multiple forms of CAOXY have been observed, varying by component proportions, temperature, and relative humidity. The most common CAOXY is the $3: 1: 12$ formation $\left(3 \mathrm{Ca}(\mathrm{OH})_{2} \cdot \mathrm{CaCl}_{2} \cdot 12\right.$ $\mathrm{H}_{2} \mathrm{O}$ ), which forms at high chloride concentrations. A comprehensive review on CAOXY is given by Jones et al. [41].

CAOXY can cause deleterious expansion in concrete exposed to de-icing salts, especially calcium or magnesium chloride salts. SCMs have been found to mitigate damage due to CAOXY formation because they reduce the amount of portlandite available in the system [42].

CAOXY may help us understand chloride binding at high chloride concentrations. They might be partly responsible for the unexplained difference between the modelled and measured chloride uptake in $\mathrm{CaCl}_{2}$ or $\mathrm{MgCl}_{2}$ exposures compared to $\mathrm{NaCl}$ exposure (see Sect. 2.1). These phases need to be included in the thermodynamic database, but collecting the necessary experimental data might be very challenging due to their high sensitivity to moisture and temperature. 


\subsection{Chloride adsorption in $\mathrm{C}(-\mathrm{A})-\mathrm{S}-\mathrm{H}$}

We have some idea of the contribution of Friedel's salt to chloride binding, but we are still quite in the dark when it comes to the contribution of C(-A)-S-H to chloride binding in hydrated cement paste, mortar or concrete. $\mathrm{C}(-\mathrm{A})-\mathrm{S}-\mathrm{H}$ is the main hydrate in Portland composite cements. It is, therefore, one of the major potential breakthrough areas in this field.

The layered structure of calcium (alumino)silicate hydrate, $\mathrm{C}(-\mathrm{A})-\mathrm{S}-\mathrm{H}$, is highly complex due to its variable stoichiometry and nano-sized morphology. $\mathrm{C}(-\mathrm{A})-\mathrm{S}-\mathrm{H}$ has now been studied for over half a century, yet the atomic structure of this nano-crystalline phase is still not fully understood. The proposed structures of C(-A)-S-H are mainly based on tobermorite, a natural mineral, which has a layered structure based on a calcium sheet flanked on each side by linear silicate chains [24, 43, 44].

The term $\mathrm{C}(-\mathrm{A})-\mathrm{S}-\mathrm{H}$, emphasizes the aluminium uptake in the C-S-H structure [24]. It is established that alumina tetrahedra (4-fold coordination) can replace silicate tetrahedra in the bridging position in $\mathrm{C}-\mathrm{S}-\mathrm{H}$ silicate chains. Aluminium has also been observed in C(-A)-S-H in 5- and 6-fold coordination. How these fit into the C(-A)-S-H structure is a subject of ongoing research [45]. Understanding $\mathrm{Al}$ uptake in $\mathrm{C}-\mathrm{S}-\mathrm{H}$ is an important topic because the use of SCMs can result in a considerable increase of aluminium uptake in the $\mathrm{C}(-\mathrm{A})-\mathrm{S}-\mathrm{H}$, both by providing more alumina to the system and perhaps also by lowering the $\mathrm{Ca} / \mathrm{Si}$ ratio of the $\mathrm{C}(-\mathrm{A})-\mathrm{S}-\mathrm{H}$ and the $\mathrm{pH}$ of the system, thereby facilitating a higher alumina uptake over time [46, 47].

The Stern electric double layer (EDL) theory ascribes the interactions between chloride ions and $\mathrm{C}(-\mathrm{A})-\mathrm{S}-\mathrm{H}$ to electrostatic interactions between ions in the pore solution and the $\mathrm{C}(-\mathrm{A})-\mathrm{S}-\mathrm{H}$ surface, rather than direct binding into the $\mathrm{C}(-\mathrm{A})-\mathrm{S}-\mathrm{H}$ structure. A comprehensive review of the Stern EDL-theory can be found in Shi et al. [8]. According to the theory, the surface of the C(-A)-S-H, which consists of silicate chains, is negatively charged due to deprotonation of silanol groups in the chains. This negatively charged surface attracts positively charged calcium ions from the pore solution in what is referred to as the Stern layer. These calcium ions cause a charge overcompensation, resulting in a net positive charge. This results in the accumulation of negatively charged chloride ions from the pore solution in what is called the diffuse layer. So, the consensus is that $\mathrm{C}(-\mathrm{A})-\mathrm{S}-\mathrm{H}$ does not directly bind chlorides, but instead accumulates chlorides in the diffuse layer depending on the amount of calcium in the Stern layer [23, 25].

If we want to understand the forces behind these surface interactions between $\mathrm{C}(-\mathrm{A})-\mathrm{S}-\mathrm{H}$ and the ions present in the pore solution, we need to dive down to the atomic scale [23]. Very promising work is being done by Svenum et al. [48], Pellenq and co-workers $[49,50]$, Churakov and co-workers [51-54], Kovacevic et al. [55, 56], and Kunhi Mohamed et al. [57] using reactive force fields combined with ab initio methods, such as density-functional theory (DFT) calculations. For example, the set-up used in Svenum et al. [48] enabled the identification of preferential sites for chlorides, and confirmed that $\mathrm{C}(-\mathrm{A})-\mathrm{S}-\mathrm{H}$ will bind chloride ions from an aqueous solution based on computed substitution energies. Quantification of this effect and investigation of its impact on chloride transport still remains to be done. In my opinion, we should invest in research in atomic scale modelling of $\mathrm{C}(-\mathrm{A})-\mathrm{S}-\mathrm{H}$, combined with experimental validation to reveal where and how chloride ions are sorbed onto the $\mathrm{C}(-\mathrm{A})-\mathrm{S}-\mathrm{H}$ and determine their mobility in the gel pores.

In addition to the enormous challenges in modelling the interaction between $\mathrm{C}(-\mathrm{A})-\mathrm{S}-\mathrm{H}$ and chloride, the experimental investigation is also complex. Many researchers, myself included (cf. Sect. 2), still obtain the chloride adsorbed by $\mathrm{C}(-\mathrm{A})-\mathrm{S}-\mathrm{H}$ in a hydrated cement paste by subtracting the chemical binding in the AFm from the total chloride binding [17, 26, 35].

The chloride content in C(-A)-S-H in hydrated cement paste can be directly measured by determining the $\mathrm{Cl} / \mathrm{Ca}$ or $\mathrm{Cl} / \mathrm{Si}$ ratio of the $\mathrm{C}(-\mathrm{A})-\mathrm{S}-\mathrm{H}$ in polished sections using SEM-EDS [17, 31, 58-62]. These ratios, combined with the quantification of the $\mathrm{C}(-\mathrm{A})$ $\mathrm{S}-\mathrm{H}$ content obtained by mass balance, for example, give the contribution of the chloride uptake by $\mathrm{C}(-\mathrm{A})$ $\mathrm{S}-\mathrm{H}$ to the total chloride content, which agrees well with the chloride taken up by $\mathrm{C}(-\mathrm{A})-\mathrm{S}-\mathrm{H}$ obtained with the above-mentioned elimination method [31, 32].

One of the main challenges with the direct method is the sample preparation, as we have pointed out $[28,35]$. The chlorides in the pore solution precipitate during the preparation of the polished sections, because they cannot be removed through solvent exchange due to their low solubility in commonly used 
solvents, e.g. ethanol [63]. So, when investigating cement pastes from equilibrium chloride binding experiments exposed to high chloride concentrations, we might overestimate the $\mathrm{Cl} / \mathrm{Si}$ or $\mathrm{Cl} / \mathrm{Ca}$ ratio of the paste due to chloride precipitation from the exposure solution.

\subsection{Binding experiments}

There are multiple methods for experimentally studying chloride binding in concrete. The literature provides overviews and comparisons of these methods $[8,12,13,64]$. The equilibrium method, in which cement paste is left to equilibrate in a chloridecontaining solution and the chloride-binding capacity is determined by the reduction in the chloride concentration in the exposure solution, is one of the most common methods of investigating chloride binding in hydrated cement paste. We should note that this method has a series of pitfalls.

First, exposure conditions during the equilibrium method may not be very representative of conditions in the field. We have recently shown that chloride ingress in concrete is linked to leaching. Positive cations, such as sodium, do not seem to accompany chloride into the concrete in an equimolar amount [39, 61, 62]. To maintain electroneutrality therefore, anions such as hydroxyl ions need to leach out. This leaching has been documented by a decrease in $\mathrm{Ca}(\mathrm{OH})_{2}$ in the exposed concrete $[39,61,65]$. In the case of $\mathrm{NaCl}$ binding isotherms, sodium and chloride are introduced to the system in equal amounts, which is not the case in concrete exposed to chloride diffusion from either $\mathrm{NaCl}$ solution or sea water $[39,61,62]$. It could be argued that $\mathrm{CaCl}_{2}$ binding isotherms do not introduce additional elements to the system (Na) and that leaching conditions can be simulated by reducing the $\mathrm{pH}$. However, as shown in Sect. 2.1, $\mathrm{CaCl}_{2}$ addition might lead to higher calcium concentrations in the solution than in the concrete, which will also affect the chloride binding.

The $\mathrm{pH}$ in the exposure solution during the equilibrium binding test might not represent the $\mathrm{pH}$ in exposed concrete. De Weerdt et al. [28, 58] and, more recently, Avet and Scrivener [32] have pointed out that the $\mathrm{pH}$ of the exposure solution during the equilibrium binding experiment depends not only on the type of cation, but also on the liquid-to-solid ratio used. As shown in this paper, leaching and $\mathrm{pH}$ have a major impact on chloride binding.

Equilibrium methods do not account for the kinetics of the various chloride binding reactions in cement paste. The ingress of chloride ions in concrete can be affected by the kinetics of the chloride binding reactions $[66,67]$. There is therefore need to investigate and understand these kinetics so they can be included in physical transport models as for example demonstrated by Tran et al. [67].

In conclusion, care should be taken when directly using equilibrium binding isotherms to predict a chloride profile for concrete exposed to chloride diffusion.

We should also note that the method used to extract the exposure solution for analysis has been found to influence the chloride concentration measured. Shi et al. [8] report that a higher chloride concentration is measured in the pore solution by pore solution expression of hardened paste samples than is found in the exposure solution. This was attributed to the eviction of chloride ions accumulated in the diffuse layer under pressure. On the other hand, Plusquellec et al. [25] found that extracting the exposure solution of very diluted suspensions by filtration can cause an overestimation of the amount of bound chlorides because chlorides will accumulate more in the diffuse layer to charge-compensate between the surfaces of the particles in the filtrate.

\subsection{Physical models}

To understand more about how chloride binding affects chloride ingress, we need to use multi-ionic physical models, which should take leaching into account. We have seen that leaching has a major impact on chloride binding [27, 28] and apparently also on chloride ingress [65, 68].

Fundamental equations such as the PoissonNernst-Planck equation [69] combined with finiteelement simulations can be used to describe the multiion transport in the pore system of concrete. There are a few existing state-of-the-art physical models for chloride ingress in concrete that combine physical transport modelling with chemical equilibrium modelling: STADIUM from Samson and Marchand [70], DuCOM from Elakneswaran and Ishida [71], and models from Hosokawa et al. [72], Tran et al. [67], Jensen et al. [69], Isgor and Weiss [73] and Michel 
et al. [74]. These models can be regarded as state-ofthe-art for reactive transport modelling in concrete. They include interactions between ions in solution and the solids, using for instance PhreeqC equilibrium calculations. A comparison of the predictions by Jensen's model with experimental data from the present author still showed large discrepancies [69], but most discrepancies between these advanced physical models and experimental data are due to the absence of a fundamental description of the interactions between chlorides and $\mathrm{C}(-\mathrm{A})-\mathrm{S}-\mathrm{H}$ and the incomplete description of chloride uptake in LDHs. These models are crucial for the upscaling of findings on chloride binding. The final aim should be to provide a simplified version of these models with fewer input parameters for engineering practice.

One concern that should be raised is the accessibility of some of these models. If the general research community is to advance in this field, open-source code is the best way forward. Universities and research institutions should therefore allow their researchers to publish their code.

\section{Outlook}

The goal of all our theoretical work on chloride binding is to be able to predict the development of chloride ingress for concretes made with new cement compositions. For this we need mechanistic models. The models need to be able to predict changes in chloride binding depending on the composition of the binder and the exposure.
Figure 10 shows how the total chloride content measured for a mortar exposed to a $3 \% \mathrm{NaCl}$ solution for 180 days can be distributed between chloride uptake by $\mathrm{C}(-\mathrm{A})-\mathrm{S}-\mathrm{H}$ and $\mathrm{AFm}$, and free chlorides in the pore solution. The amounts of the phases were estimated by thermodynamic modelling, but in the absence of suitable models, the chloride binding had to be determined experimentally [68]. We need to be able to predict this, so we need to understand and be able to model chloride binding in $\mathrm{C}(-\mathrm{A})-\mathrm{S}-\mathrm{H}$, and we need additional thermodynamic data for $\mathrm{AFm}$ and other hydration phases. The binding models also need to take leaching of e.g. potassium, calcium and hydroxyl ions into account, because chloride ingress goes handin-hand with leaching, as shown by the decreasing portlandite profiles towards the exposed surface in Fig. 10.

If researchers were able to predict the bound and free chlorides in multi-ionic numerical models, we would be able to develop more accurate and reliable mechanistic service life models. This would provide engineers with tools to design more sustainable and durable reinforced concrete structures, as well as to assess more accurately the remaining service life of existing structures. This would improve the management and maintenance of the existing infrastructure.

Specifically, mechanistic chloride ingress models would enable faster implementation of the new low$\mathrm{CO}_{2}$ binders we so urgently need to reduce $\mathrm{CO}_{2}$ emissions. Some experimental verification of the models would still be need to be done, but we would not have to rely so much on enormous testing campaigns and long-term data from field exposure to

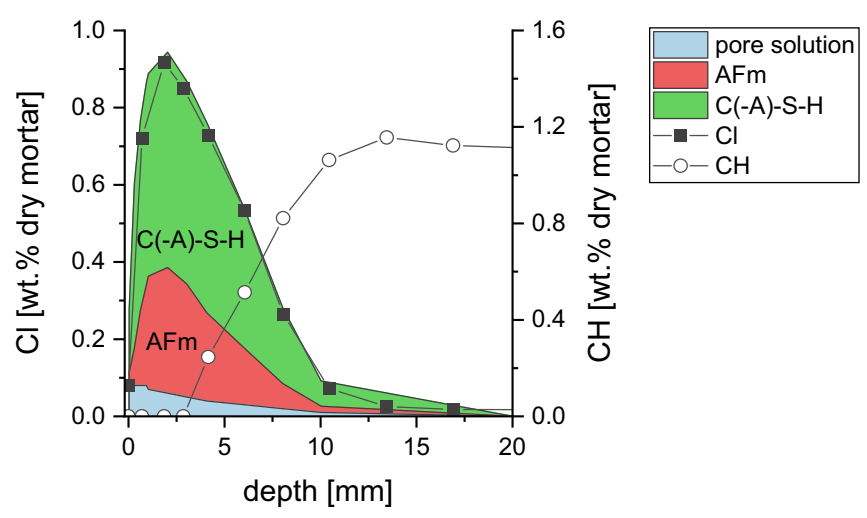

Fig. 10 Chloride $(\mathrm{Cl})$ and portlandite $(\mathrm{CH})$ profiles for mortars exposed to $3 \% \mathrm{NaCl}$ solution for 180 days. The total chloride content is distributed between the pore solution, $\mathrm{Cl}-\mathrm{AFm}$, and
$\mathrm{C}(-\mathrm{A})-\mathrm{S}-\mathrm{H}$, based on thermodynamic modelling, and SEMEDS was used to determine the actual chloride content in the $\mathrm{Cl}$ AFm and C(-A)-S-H Machner A et al. [68] 
gather sufficient experimental data to fit the empirical service life models.

If engineers were able to predict the development of chloride ingress over time for multiple cement compositions and exposure conditions, they would be able to optimize their choice of cement composition with regard to sustainability and durability with far greater accuracy than permitted by the current deemed-tosatisfy rules provided in standards and regulations. This would enable a more sustainable use of reinforced concrete as a building material.

We also want the mechanistic chloride ingress models to be more reliable for long-term predictionbased on physics and chemistry rather than on curvefitting and questionable ageing factors. Higher precision models are required as more advanced structures are being built, such as floating subsea tunnels, for which we want a reliable service life of up to several hundred years.

Tools to design more sustainable and durable reinforced concrete infrastructure as well as improved management of existing structures would benefit not only engineers and structure owners, but also society as a whole, which depends on this infrastructure.

Acknowledgements First, I want to express my enormous gratitude to my $\mathrm{PhD}$ and postdoc supervisors and mentors, Harald Justnes, Knut O. Kjellsen, Barbara Lothenbach, and Mette R. Geiker, who enabled me to work on very exciting research topics, encouraged me on my path, and with whom I have had so many good discussions. Thank you also to my colleagues at SINTEF and NTNU for providing me with solid research training in a wonderful team of friends and experts. The work presented in this paper has been a team effort. At times I was in the driving seat; at others I was one of the passengers. A big thank-you to all the master students, $\mathrm{PhD}$ students and postdocs I have shared these projects with: Alessia Colombo, Denisa Orsakova, Arnaud Muller, Silje Gystad Ytterdal, Gilles Plusquellec, Zhenguo Shi, Andres Belda Revert, Arezou Baba Ahmadi, Tobias Danner, Petter Hemstad, Simon Fjendbo, Marie Bjørndalen, and Alisa Machner, as well as all our international collaborators. Thanks also to all our partners in industry and government who have supported our research and given us access to invaluable field samples. It was the Norwegian COncrete INnovation (COIN) centre that gave my research career a kick-start and got me hooked on concrete research. Other national organizations, such as the Norwegian Concrete Association, as well as international networks, such as Nanocem (now Innovandi) and RILEM have also played an extremely important role in promoting collaboration and creating an inspiring and challenging environment for researchers and practitioners. Last, but not least, thanks to my family and friends for coping with my enthusiasm for concrete.
Open Access This article is licensed under a Creative Commons Attribution 4.0 International License, which permits use, sharing, adaptation, distribution and reproduction in any medium or format, as long as you give appropriate credit to the original author(s) and the source, provide a link to the Creative Commons licence, and indicate if changes were made. The images or other third party material in this article are included in the article's Creative Commons licence, unless indicated otherwise in a credit line to the material. If material is not included in the article's Creative Commons licence and your intended use is not permitted by statutory regulation or exceeds the permitted use, you will need to obtain permission directly from the copyright holder. To view a copy of this licence, visit http://creativecommons.org/licenses/by/4.0/.

Funding Open access funding provided by NTNU Norwegian University of Science and Technology (incl St. Olavs Hospital Trondheim University Hospital).

\section{References}

1. Angst UM (2018) Challenges and opportunities in corrosion of steel in concrete. Mater Struct 51(1):4. https://doi.org/10. 1617/s11527-017-1131-6

2. Fib (2006) Model code for service life design. fib Bulletin 34. CEB-FIB

3. ISO 16204 (2012) Durability - Service life design of concrete structures

4. International Energy Agency (2018) Technology roadmapLow-carbon transition in the cement industry

5. Scrivener KL, John VM, Gartner EM (2018) Eco-efficient cements: Potential economically viable solutions for a low$\mathrm{CO}_{2}$ cement-based materials industry. Cem Concr Res 114:2-26. https://doi.org/10.1016/j.cemconres.2018.03.015

6. Shi Z, Geiker MR, Lothenbach B, De Weerdt K, Garzón SF, Enemark-Rasmussen K, Skibsted J (2017) Friedel's salt profiles from thermogravimetric analysis and thermodynamic modelling of Portland cement-based mortars exposed to sodium chloride solution. Cement Concr Compos 78:73-83. https://doi.org/10.1016/j.cemconcomp.2017.01. 002

7. Maraghechi H, Avet F, Wong H, Kamyab H, Scrivener KL (2018) Performance of limestone calcined clay cement (LC3) with various kaolinite contents with respect to chloride transport. Mater Struct 51(5):125. https://doi.org/10. 1617/s11527-018-1255-3

8. Shi C, Yuan Q, He F, Hu X (2019) Transport and Interactions of Chlorides in Cement-Based Materials. CRC Press, London

9. Tang L, Nilsson L-O, Muhammed Basheer PA (2012) Resistance of concrete to chloride ingress - testing and modelling. CRC Press, London

10. Bertolini L, Elsener B, Pedeferri P, Redaelli E, Polder RB (2014) Corrosion of steel in concrete: Prevention, diagnosis, repair, 2nd edn. Singapore, Wiley

11. Justnes H (1998) A review of chloride binding in cementitious systems. Nordic Concr Res 21:48-63 
12. Yuan Q, Shi C, De Schutter G, Audenaert K, Deng D (2009) Chloride binding of cement-based materials subjected to external chloride environment - a review. Constr Build Mater 23(1):1-13. https://doi.org/10.1016/j.conbuildmat. 2008.02.004

13. Zibara H (2001) Binding of external chlorides by cement pastes. PhD thesis, University of Toronto, Canada

14. Kulik DA, Wagner T, Dmytrieva SV, Kosakowski G, Hingerl FF, Chudnenko KV, Berner UR (2013) GEMSelektor geochemical modeling package: revised algorithm and GEMS3K numerical kernel for coupled simulation codes. Comput Geosci 17:1-24. https://doi.org/10.1007/ s10596-012-9310-6

15. Lothenbach B, Kulik DA, Matschei T, Balonis M, Baquerizo L, Dilnesa B, Miron GD, Myers RJ (2019) Cemdata18: a chemical thermodynamic database for hydrated Portland cements and alkali-activated materials. Cem Concr Res 115:472-506. https://doi.org/10.1016/j.cemconres.2018.04. 018

16. Balonis M, Lothenbach B, Le Saout G, Glasser FP (2010) Impact of chloride on the mineralogy of hydrated Portland cement systems. Cem Concr Res 40(7):1009-1022. https:// doi.org/10.1016/j.cemconres.2010.03.002

17. De Weerdt K, Colombo A, Coppola L, Justnes H, Geiker MR (2015) Impact of the associated cation on chloride binding of Portland cement paste. Cem Concr Res 68:196-202. https://doi.org/10.1016/j.cemconres.2014.01. 027

18. Tritthart J (1989) Chloride binding in cement II. The influence of the hydroxide concentration in the pore solution of hardened cement paste on chloride binding. Cement Concr Res 19(5):683-691

19. Arya C, Buenfeld NR, Newman JB (1990) Factors influencing chloride-binding in concrete. Cem Concr Res 20(2):291-300. https://doi.org/10.1016/00088846(90)90083-A

20. Wowra O, Setzer MJ (1997) Sorption of chlorides on hydrated cement and $\mathrm{C}_{3} \mathrm{~S}$ pastes. In: Setzer MJ, Auberg R (eds) Frost resistance of concrete. E \& FN Spon, London, pp 147-153

21. Delagrave A, Marchand J, Ollivier J-P, Julien S, Hazrati K (1997) Chloride binding capacity of various hydrated cement paste systems. Adv Cem Based Mater 6(1):28-35. https://doi.org/10.1016/S1065-7355(97)90003-1

22. Zhu Q, Jiang L, Chen Y, Xu J, Mo L (2012) Effect of chloride salt type on chloride binding behavior of concrete. Constr Build Mater 37:512-517. https://doi.org/10.1016/j. conbuildmat.2012.07.079

23. Labbez C, Pochard I, Jönsson B, Nonat A (2011) C-S$\mathrm{H} /$ solution interface: experimental and Monte Carlo studies. Cem Concr Res 41(2):161-168. https://doi.org/10.1016/j. cemconres.2010.10.002

24. Lothenbach B, Nonat A (2015) Calcium silicate hydrates: solid and liquid phase composition. Cement Concr Res 78(A):57-70

25. Plusquellec G, Nonat A (2016) Interactions between calcium silicate hydrate $(\mathrm{C}-\mathrm{S}-\mathrm{H})$ and calcium chloride, bromide and nitrate. Cem Concr Res 90:89-96. https://doi.org/ 10.1016/j.cemconres.2016.08.002

26. Shi Z, Geiker MR, De Weerdt K, Østnor TA, Lothenbach B, Winnefeld F, Skibsted J (2017) Role of calcium on chloride binding in hydrated Portland cement-metakaolin-limestone blends. Cem Concr Res 95:205-216. https://doi.org/10. 1016/j.cemconres.2017.02.003

27. Machner A, Hemstad P, De Weerdt K (2018) Towards the understanding of the $\mathrm{pH}$ dependency of the chloride binding of portland cement pastes. Nordic Concr Res 58(1):143-162. https://doi.org/10.2478/ncr-2018-0009

28. Hemstad P, Machner A, De Weerdt K (2020) The effect of artificial leaching with $\mathrm{HCl}$ on chloride binding in ordinary Portland cement paste. Cem Concr Res 130:105976. https:// doi.org/10.1016/j.cemconres.2020.105976

29. Machner A, Zajac M, Ben Haha M, Kjellsen KO, Geiker MR, De Weerdt K (2018) Stability of the hydrate phase assemblage in Portland composite cements containing dolomite and metakaolin after leaching, carbonation, and chloride exposure. Cement Concr Compos 89:89-106. https://doi.org/10.1016/j.cemconcomp.2018.02.013

30. Georget F, Bénier C, Wilson W, Scrivener KL (2021) Chloride sorption by C-S-H quantified by SEM-EDX image analysis. Cem Concr Res. https://doi.org/10.13140/RG.2.2. 27195.54562/1

31. Sui S, Wilson W, Georget F, Maraghechi H, KazemiKamyab H, Sun W, Scrivener K (2019) Quantification methods for chloride binding in Portland cement and limestone systems. Cem Concr Res 125:105864. https://doi. org/10.1016/j.cemconres.2019.105864

32. Avet F, Scrivener KL (2020) Influence of $\mathrm{pH}$ on the chloride binding capacity of limestone calcined clay cements $\left(\mathrm{LC}^{3}\right)$. Cem Concr Res 131:106031. https://doi.org/10.1016/j. cemconres.2020.106031

33. Thomas MDA, Hooton RD, Scott A, Zibara H (2012) The effect of supplementary cementitious materials on chloride binding in hardened cement paste. Cem Concr Res 42(1):1-7. https://doi.org/10.1016/j.cemconres.2011.01. 001

34. Beaudoin JJ, Ramachandran VS, Feldman RF (1990) Interaction of chloride and CSH. Cem Concr Res 20(6):875-883. https://doi.org/10.1016/00088846(90)90049-4

35. Machner A, Zajac M, Ben Haha M, Kjellsen KO, Geiker MR, De Weerdt K (2018) Chloride-binding capacity of hydrotalcite in cement pastes containing dolomite and metakaolin. Cem Concr Res 107:163-181. https://doi.org/ 10.1016/j.cemconres.2018.02.002

36. Baba Ahmadi A, Machner A, Kunther W, Hemstad P, De Weerdt K (2021) Chloride binding in Portland composite cements. Cem Concr Res (Submitted)

37. Ke X, Bernal SA, Provis JL (2017) Uptake of chloride and carbonate by $\mathrm{Mg}-\mathrm{Al}$ and $\mathrm{Ca}-\mathrm{Al}$ layered double hydroxides in simulated pore solutions of alkali-activated slag cement. Cem Concr Res 100:1-13. https://doi.org/10.1016/j. cemconres.2017.05.015

38. Kocaba V (2009) Development and evaluation of methods to follow microstructural development of cementitious systems including slags. PhD thesis, EPFL, Switzerland. https://doi.org/10.5075/epfl-thesis-4523

39. De Weerdt K, Lothenbach B, Geiker MR (2019) Comparing chloride ingress from seawater and $\mathrm{NaCl}$ solution in Portland cement mortar. Cem Concr Res 115:80-89. https://doi. org/10.1016/j.cemconres.2018.09.014 
40. Kayali O, Khan MSH, Sharfuddin Ahmed M (2012) The role of hydrotalcite in chloride binding and corrosion protection in concretes with ground granulated blast furnace slag. Cement Concr Compos 34(8):936-945. https://doi. org/10.1016/j.cemconcomp.2012.04.009

41. Jones C, Ramanathan S, Suraneni P, Hale WM (2020) Calcium oxychloride: a critical review of the literature surrounding the formation, deterioration, testing procedures, and recommended mitigation techniques. Cement Concr Compos 113:103663. https://doi.org/10.1016/j. cemconcomp.2020.103663

42. Suraneni P, Azad VJ, Isgor BO, Weiss WJ (2016) Calcium oxychloride formation in pastes containing supplementary cementitious materials: thoughts on the role of cement and supplementary cementitious materials reactivity. RILEM Tech Lett 1:24-30

43. Taylor HFW (1997) Cement chemistry, 2nd edn. London, Academic Press

44. Richardson IG (2014) Model structures for C-(A)-S-H(I). Acta Crystallogr B 70(6):903-923. https://doi.org/10.1107/ S2052520614021982

45. Kunhi Mohamed A, Moutzouri P, Berruyer P, Walder BJ, Siramanont J, Harris M, Negroni M, Galmarini SC, Parker SC, Scrivener KL, Emsley L, Bowen P (2020) The atomiclevel structure of cementitious calcium aluminate silicate hydrate. J Am Chem Soc 142(25):11060-11071. https://doi. org/10.1021/jacs.0c02988

46. Barzgar S, Lothenbach B, Tarik M, Di Giacomo A, Ludwig C (2020) The effect of sodium hydroxide on Al uptake by calcium silicate hydrates (CSH). J Coll Interface Sci 572:246-256. https://doi.org/10.1016/j.jcis.2020.03.057

47. Barzgar S, Tarik M, Ludwig C, Lothenbach B (2021) The effect of equilibration time on Al uptake in C-S-H. Cem Concr Res 144:106438. https://doi.org/10.1016/j. cemconres.2021.106438

48. Svenum I-H, Ringdalen IG, Bleken FL, Friis J, Höche D, Swang O (2020) Structure, hydration, and chloride ingress in C-S-H: Insight from DFT calculations. Cem Concr Res 129:105965. https://doi.org/10.1016/j.cemconres.2019. 105965

49. Pellenq RJM, Kushima A, Shahsavari R, Van Vliet KJ, Buehler MJ, Yip S, Ulm F-J (2009) A realistic molecular model of cement hydrates. Proc Natl Acad Sci 106(38):16102-16107. https://doi.org/10.1073/pnas. 0902180106

50. Abdolhosseini Qomi MJ, Krakowiak KJ, Bauchy M, Stewart KL, Shahsavari R, Jagannathan D, Brommer DB, Baronnet A, Buehler MJ, Yip S, Ulm FJ, Van Vliet KJ, Pellenq RJM (2014) Combinatorial molecular optimization of cement hydrates. Nat Commun 5:4960. https://doi.org/ $10.1038 /$ ncomms5960

51. Churakov SV (2009) Structure of the interlayer in normal 11 A tobermorite from an ab initio study. Eur J Mineral 21(1):261-271. https://doi.org/10.1127/0935-1221/2009/ 0021-1865

52. Churakov SV (2009) Structural position of $\mathrm{H}_{2} \mathrm{O}$ molecules and hydrogen bonding in anomalous $11 \AA$ tobermorite. Am Miner 94(1):156-165. https://doi.org/10.2138/am.2009. 2907

53. Churakov SV, Labbez C (2017) Thermodynamics and molecular mechanism of $\mathrm{Al}$ incorporation in calcium silicate hydrates. The J Phys Chem C 121(8):4412-4419. https://doi.org/10.1021/acs.jpcc.6b12850

54. Krattiger N, Lothenbach B, Churakov SV (2021) Sorption and electrokinetic properties of ASR product and C-S-H: a comparative modelling study. Cem Concr Res 146:106491. https://doi.org/10.1016/j.cemconres.2021.106491

55. Kovačević G, Persson B, Nicoleau L, Nonat A, Veryazov V (2015) Atomistic modeling of crystal structure of $\mathrm{Ca}_{1.67-}$ $\mathrm{SiH}_{\mathrm{x}}$. Cem Concr Res 67:197-203. https://doi.org/10.1016/ j.cemconres.2014.09.003

56. Kovačević G, Nicoleau L, Nonat A, Veryazov V (2016) Revised atomistic models of the crystal structure of C-S-H with high C/S ratio. Z Phys Chem 230(9):1411-1424. https://doi.org/10.1515/zpch-2015-0718

57. Kunhi Mohamed A, Parker SC, Bowen P, Galmarini S (2018) An atomistic building block description of C-S-H towards a realistic C-S-H model. Cem Concr Res 107:221-235. https://doi.org/10.1016/j.cemconres.2018.01. 007

58. De Weerdt K, Orsáková D, Geiker MR (2014) The impact of sulphate and magnesium on chloride binding in Portland cement paste. Cem Concr Res 65:30-40. https://doi.org/10. 1016/j.cemconres.2014.07.007

59. De Weerdt K, Justnes H (2015) The effect of sea water on the phase assemblage of hydrated cement paste. Cement Concr Compos 55:215-222. https://doi.org/10.1016/j. cemconcomp.2014.09.006

60. De Weerdt K, Justnes H, Geiker MR (2014) Changes in the phase assemblage of concrete exposed to sea water. Cement Concr Compos 47:53-63. https://doi.org/10.1016/j. cemconcomp.2013.09.015

61. De Weerdt K, Orsáková D, Müller ACA, Larsen CK, Pedersen B, Geiker MR (2016) Towards the understanding of chloride profiles in marine exposed concrete, impact of leaching and moisture content. Constr Build Mater 120:418-431. https://doi.org/10.1016/j.conbuildmat.2016. 05.069

62. Jakobsen UH, De Weerdt K, Geiker MR (2016) Elemental zonation in marine concrete. Cem Concr Res 85:12-27. https://doi.org/10.1016/j.cemconres.2016.02.006

63. Arya C, Buenfeld NR, Newman JB (1987) Assessment of simple methods of determining the free chloride ion content of cement paste. Cem Concr Res 17(6):907-918. https://doi. org/10.1016/0008-8846(87)90079-2

64. Tang L, Nilsson L-O (1993) Chloride binding capacity and binding isotherms of OPC pastes and mortars. Cem Concr Res 23(2):247-253. https://doi.org/10.1016/00088846(93)90089-R

65. Machner A, Bjorndal M, Sajna A, Mikanovic N, Weerdt KD (2021) Impact of leaching on chloride ingress profiles in concrete. Materials and Structures, (accepted for publication)

66. Spiesz P, Ballari MM, Brouwers HJH (2012) RCM: a new model accounting for the non-linear chloride binding isotherm and the non-equilibrium conditions between the freeand bound-chloride concentrations. Constr Build Mater 27(1):293-304. https://doi.org/10.1016/j.conbuildmat. 2011.07.045

67. Tran VQ, Soive A, Baroghel-Bouny V (2018) Modelisation of chloride reactive transport in concrete including thermodynamic equilibrium, kinetic control and surface 
complexation. Cem Concr Res 110:70-85. https://doi.org/ 10.1016/j.cemconres.2018.05.007

68. Machner A, Bjørndal MH, Justnes H, Hanzic L, Sajna A, Gu Y, Bary B, Ben Haha M, Geiker MR, De Weerdt K (2021) Effect of leaching on the composition of the hydration phases during chloride exposure of mortar. Cem Concr Res (Submitted)

69. Jensen MM, De Weerdt K, Johannesson B, Geiker MR (2015) Use of a multi-species reactive transport model to simulate chloride ingress in mortar exposed to $\mathrm{NaCl}$ solution or sea-water. Comput Mater Sci 105:75-82. https://doi. org/10.1016/j.commatsci.2015.04.023

70. Samson E, Marchand J (2007) Modeling the transport of ions in unsaturated cement-based materials. Comput Struct 85(23):1740-1756. https://doi.org/10.1016/j.compstruc. 2007.04.008

71. Elakneswaran Y, Ishida T (2012) Development of a physical and geochemical model for long-term performance of cementitious material. Internet $\mathrm{J}$ Soc Soc Manag Syst 8(1):SMS12-0768
72. Hosokawa Y, Yamada K, Johannesson B, Nilsson L-O (2011) Development of a multi-species mass transport model for concrete with account to thermodynamic phase equilibriums. Mater Struct 44(9):1577-1592. https://doi. org/10.1617/s11527-011-9720-2

73. Isgor OB, Weiss WJ (2019) A nearly self-sufficient framework for modelling reactive-transport processes in concrete. Mater Struct 52:3. https://doi.org/10.1617/s11527-0181305-X

74. Michel A, Marcos-Meson V, Kunther W, Geiker MR (2021) Microstructural changes and mass transport in cementbased materials: a modeling approach. Cem Concr Res 139:106285. https://doi.org/10.1016/j.cemconres.2020. 106285

Publisher's Note Springer Nature remains neutral with regard to jurisdictional claims in published maps and institutional affiliations. 